\title{
HYPEROSMOTIC APPLICATIONS OF KCI INDUCE VASCULAR SMOOTH MUSCLE CONTRACTION WHICH IS INDEPENDENT OF EXTERNAL Ca
}

\author{
Hideaki KARAKI, Hee Yul AHN and Norimoto URAKAWA \\ Department of Veterinary Pharmacology, Faculty of Agriculture. \\ University of Tokyo, Bunkyo-ku. Tokyo 113. Japan
}

Accepted August 21, 1982

$\mathrm{K}$-induced contraction is widely used in studies on excitation-contraction coupling in smooth muscle and is also utilized as a standard contraction in the evaluation of smooth muscle relaxants. It has become accepted that K-induced contraction in smooth muscle is the result of $\mathrm{Ca}$ influx from the extracellular medium through a voltagesensitive $\mathrm{Ca}$ channel. A solution containing a high concentration of $\mathrm{K}$ is prepared either by substituting $\mathrm{NaCl}$ with isosmolar $\mathrm{KCl}$ or by adding $\mathrm{KCl}$ hyperosmotically to the physiological solution. In this communication we report that the hyperosmotic application of $\mathrm{KCl}$ induces a contraction in vascular smooth muscle which is independent of external Ca.

Media-intimal layer of rabbit thoracic aorta was prepared as described by Karaki and Urakawa (1). Sections of taenia coli were dissected from the caecum of male guinea pigs. Isometric contractile tension of the smooth muscle preparations was recorded under a resting tension of $1 \mathrm{~g}$ for aorta and $0.2 \mathrm{~g}$ for taenia coli. The normal physiological solution used was (in $\mathrm{mM}$ ): $\mathrm{NaCl}, 136.9$ : $\mathrm{KCl}$, 5.4: $\mathrm{CaCl}_{2}, 1.5 ; \mathrm{MgCl}_{2}, 1.0 ; \mathrm{NaHCO}_{3}$, 24.0: and glucose, 5.5, $\mathrm{pH} 7.4$, at $37^{\circ} \mathrm{C}$, and bubbled with a $95 \% \mathrm{O}_{2}$ and $5 \% \mathrm{CO}_{2}$ mixture (2).

In the aorta, cumulative, hyperosmotic applications of $\mathrm{KCl}$ induced a graded contraction which reached a maximum when the concentration of $\mathrm{KCl}$ was $40 \mathrm{mM}$. Further increase in the concentration of $\mathrm{KCl}$ did not change the developed tension level. In a Ca-free solution containing $0.5 \mathrm{mM}$ ethyleneglycol bis ( $\beta$-aminoethylether) - N,N,N', N'tetraacetic acid (EGTA). cumulative application of $\mathrm{KCl}$ unexpectedly induced a graded contraction. As shown in Fig. 1 , hyperosmotic applications of $60 \mathrm{mM}$ and $80 \mathrm{mM} \mathrm{KCl}$ to the Ca-free solution induced contractions of approximately $15 \%$ and $50 \%$. respectively, of that induced in the presence of $\mathrm{Ca}$. Additional increase in the concentration of added $\mathrm{KCl}$ further increased the

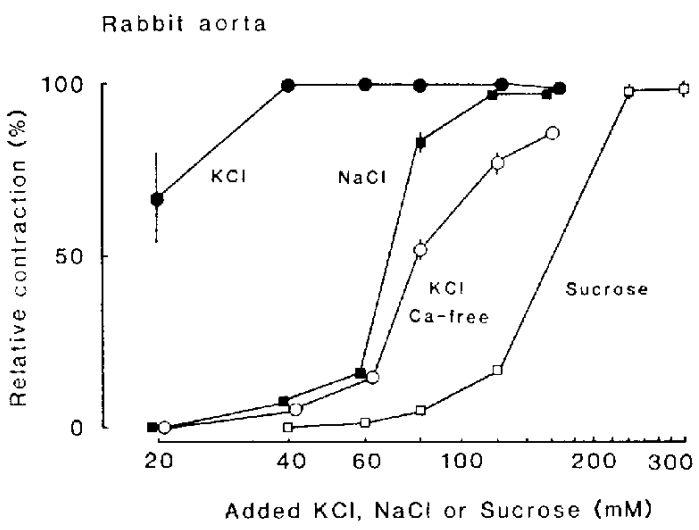

Fig. 1. Effects of hyperosmotic applications of $\mathrm{KCl}$, $\mathrm{NaCl}$ or sucrose on muscle tension in the mediaintimal layer of rabbit aorta. Ordinate: isometric muscle tension relative to the maximum contraction induced by $\mathrm{KCl}$ in the presence of $1.5 \mathrm{mM} \mathrm{Ca}$. Abscissa: concentration ( $\mathrm{mM}$ ) of added $\mathrm{KCl}, \mathrm{NaCl}$ or sucrose. Ca-free: Ca depleted solution containing $0.5 \mathrm{mM}$ EGTA. Points are means \pm S.E. of 4 to 6 experiments. 
muscle tension. A similar concentrationresponse relationship in terms of added $\mathrm{KCl}$ was obtained in a solution containing both $1.5 \mathrm{mM} \mathrm{Ca}$ and $1 \times 10^{-6} \mathrm{M}$ verapamil. The same concentration $\left(1 \times 10^{-6} \mathrm{M}\right)$ of verapamil completely inhibited the muscle contraction induced by isosmotic $80 \mathrm{mM}$ or $160 \mathrm{mM} \mathrm{KCl}$ solution made by substituting $\mathrm{KCl}$ for equimolar $\mathrm{NaCl}$ in the normal solution. Thus, at least a part of the muscle contraction induced by a hyperosmotic $\mathrm{KCl}$ solution was independent of external Ca. Hyperosmotic applications of $\mathrm{NaCl}$ or sucrose also induced muscle contractions (Fig. 1). The contractions induced by the hyperosmotic application of $\mathrm{NaCl}$ or sucrose were not affected by inhibitors of K-induced contraction (removal of $\mathrm{Ca}$ from the medium or the application of $1 \times 10^{-5} \mathrm{M}$ verapamil), an inhibitor of norepinephrine-induced contraction $\left(1 \times 10^{-5} \mathrm{M}\right.$ sodium nitroprusside), or nonspecific smooth muscle relaxants $\left(1 \times 10^{-4} \mathrm{M}\right.$ papaverine, $2 \times 10^{-5} \mathrm{M}$ chlorpromazine or $1 \times 10^{-4} \mathrm{M} \mathrm{N}$ (6-aminohexyl) -5-chloro-1-naphthalenesulfonamide $(W-7))$. However, the contractions induced by the hyperosmotic solutions rapidly relaxed when the muscle strips were washed with normal physiological solution, and the ability of the muscle to respond to norepinephrine was not affected by the previous treatment of the muscle with the hyperosmotic solution.

In guinea pig taenia coli, cumulative applications of $\mathrm{KCl}$ induced a muscle contraction which reached a maximum when $20 \mathrm{mM} \mathrm{KCl}$ was added. As the $\mathrm{KCl}$ concentration was increased further, there was little change in developed tension until at $120 \mathrm{mM}$ $\mathrm{KCl}$ and above. the tension was sharply decreased as shown in Fig. 2. This may possibly be an effect of hyperosmolarity in inhibiting excitation-contraction coupling (3). In the absence of external Ca (Fig. 2) or in the presence of $1 \times 10^{-6} \mathrm{M}$ verapamil, the hyperosmotic applications of $\mathrm{KCl}$ at $80 \mathrm{mM}$

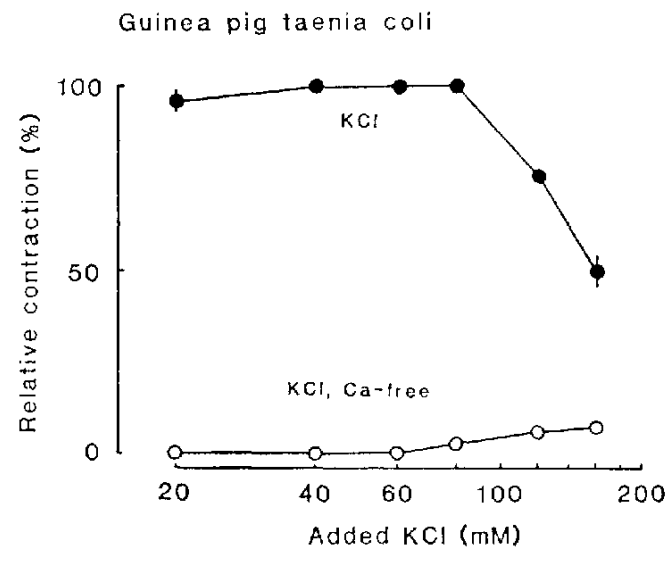

Fig. 2. Effects of hyperosmotic applications of $\mathrm{KCl}$ on muscle tension in the guinea pig taenia coli in tho presence or absence of $1.5 \mathrm{mM} \mathrm{Ca}$. Means \pm S.E. of 4 to 6 experiments are shown.

and above induced small contractions.

From these results, it is concluded that hyperosmolarity induces a contraction in smooth muscle. especially in rabbit aorta. The contraction induced in aorta by either $\mathrm{NaCl}$ or sucrose in normal $\mathrm{Ca}$ was slightly greater than that induced by $\mathrm{KCl}$ at the same osmolarity in the absence of added $\mathrm{Ca}$. This may be because $\mathrm{KCl}$ is more permeable than $\mathrm{NaCl}$ or sucrose in smooth muscle (4). Smooth muscle cells usually behave as perfect osmometers with respect to the addition of non-permeable solutes to the normal medium (5), and hyperosmotic addition of $\mathrm{KCl}$ also decreases cell water content (6). The muscle contraction induced by hyperosmolarity (addition of $\mathrm{KCl}$ without $\mathrm{Ca}$, addition of $\mathrm{NaCl}$ or sucrose) was independent of external $\mathrm{Ca}$ and was not affected by various smooth muscle relaxants, suggesting that this contraction may not be attributed to events related to a physiological excitation-contraction coupling process. One possible explanation for this contraction is an osmotic shrinkage of the muscle tissue. However, we do not have available data to explain the difference between rabbit aorta and guinea pig taenia coli. In previous reports $(7,8)$, it 
was found that isosmotic substitution of $\mathrm{KCl}$ for $\mathrm{NaCl}$ inhibits smooth muscle contraction by inhibiting the co-transport of glucose with $\mathrm{Na}$ and/or by the swelling of the smooth muscle cells induced by high concentration of permeable ions, $\mathrm{K}$ and $\mathrm{Cl}$. Therefore, care should be taken with the $\mathrm{Na}$ concentration as well as the osmolarity of the medium when a high concentration of $K$ is used in studies of smooth muscle contraction.

Acknowledgements: We are grateful to Dr. Phyllis Kutsky, Department of Pharmacology. University of Texas Health Science Center at Dallas for a critical reading of this manuscript and also to Dr. Kazuyasu Murakami of our Department for his technical assistance.

\section{References}

1) Karaki, H. and Urakawa, N.: Possible role of endogenous catecholamines in the contraction induced in rabbit aorta by ouabain, sodium depletion and potassium depletion. Eur. J. Pharmacol. 43, 65-72 (1977)

2) Karaki, H., Suzuki, T. and Urakawa, N.: Tris does not inhibit isolated vascular or intestinal smooth muscle contraction. Am. J. Physiol. 241, H337-H341 (1981)

3) Somlyo, A.P. and Somlyo, A.V.: Vascular smooth muscle. II. Pharmacology of normal and hypertensive vessels. Pharmacol. Rev. $22,249-353$ (1970)

4) Jones, A.W., Somlyo, A.P. and Somlyo, A.V.: Potassium accumulation in smooth muscle and associated ultrastructural changes. J. Physiol. 232, 247-273 (1973)

5) Brading, A.F.: Osmotic phenomena in smooth muscle. In Smooth Muscle. Edited by Bülbring. E., Brading, A.F., Jones, A.W. and Tomita, T., p. 166-196. Edward Arnold Ltd.. London (1970)

6) Karaki, H., Suzuki, T. and Urakawa, N.: Changes in tissue weight and calcium content in various high potassium solutions in smooth muscle of guinea pig taenia coli. Japan. J. Pharmacol. 28, 633-636 (1978)

7) Suzuki, T., Karaki, H. and Urakawa, N.: Mechanism of inhibition of contraction by high $\mathrm{K} . \mathrm{Na}$ deficient solution in smooth muscle of guinea pig taenia coli. Arch. Int. Pharmacodvn. Ther. 248, 43-49 (1980)

8) Suzuki, T., Karaki, H. and Urakawa, N.: Inhibition of contraction by swelling of vascular smooth muscle in high $\mathrm{KCl}$, low $\mathrm{Na}$ solution. Arch. Int. Pharmacadyn. Ther. 250, 195-203 (1981) 